\title{
Composite Gel Fabricated with Konjac Glucomannan and Carrageenan Could Be Used as a Cube Fat Substitute to Partially Replace Pork Fat in Harbin Dry Sausages
}

\author{
Jiaxin Chen ${ }^{1}$, Jinhai Zhao ${ }^{2}$, Xin Li ${ }^{3}$, Qian Liu ${ }^{1,4, *}$ and Baohua Kong ${ }^{1, *(1)}$ \\ 1 College of Food Science, Northeast Agricultural University, Harbin 150030, China; \\ chenjiaxin993523@hotmail.com \\ 2 Institute for Advanced Technology, Heilongjiang Academy of Sciences, Harbin 150001, China; \\ zjh345729635@hotmail.com \\ 3 Sharable Platform of Large-Scale Instruments \& Equipments, Northeast Agricultural University, \\ Harbin 150030, China; lixin810910@hotmail.com \\ 4 Heilongjiang Green Food Science \& Research Institute, Harbin 150028, China \\ * Correspondence: liuqian@neau.edu.cn (Q.L.); kongbh63@hotmail.com (B.K.); \\ Tel.: +86-451-5519-0675 (Q.L.); +86-451-5519-1794 (B.K.)
}

check for

updates

Citation: Chen, J.; Zhao, J.; Li, X.; Liu, Q.; Kong, B. Composite Gel Fabricated with Konjac Glucomannan and Carrageenan Could Be Used as a Cube Fat Substitute to Partially Replace Pork Fat in Harbin Dry Sausages. Foods 2021, 10, 1460. https://doi.org/10.3390/ foods10071460

Academic Editor: Wangang Zhang

Received: 22 May 2021

Accepted: 21 June 2021

Published: 24 June 2021

Publisher's Note: MDPI stays neutral with regard to jurisdictional claims in published maps and institutional affiliations.

Copyright: (c) 2021 by the authors. Licensee MDPI, Basel, Switzerland. This article is an open access article distributed under the terms and conditions of the Creative Commons Attribution (CC BY) license (https:/ / creativecommons.org/licenses/by/ $4.0 /)$.

\begin{abstract}
The effect of the partial replacement of pork back-fat with a cube fat substitute (CFS) fabricated from konjac glucomannan and carrageenan on the physicochemical and sensory characteristics of Harbin dry sausages during 7 days of fermentation was investigated. There were the following five treatments: control (100\% back-fat), FS1 (80\% back-fat, 20\% CFS), FS2 (60\% back-fat, 40\% CFS), FS3 (40\% back-fat, $60 \%$ CFS) and FS4 (20\% back-fat, $80 \%$ CFS). The results showed no significant differences $(p>0.05)$ in the physicochemical and sensory characteristics among the control, FS1 and FS2 treatments. However, higher replacement levels $(60 \%$ and $80 \%)$ rendered higher degrees of change in the characteristics of the sausages, lowering the moisture content and $a_{\mathrm{w}}$ and increasing the $\mathrm{pH}$, hardness, chewiness and atypical appearance at the end of fermentation. Moreover, electronic nose analysis and hierarchical cluster analysis demonstrated that the FS3 and FS4 treatments destroyed the characteristic quality of the sausage. Overall, our results indicated that, to ensure the traditional characteristics of Harbin dry sausages, the upper limit of the fat replacement level with CFS should be set at $40 \%$.
\end{abstract}

Keywords: Harbin dry sausage; back-fat partial substitution; cube fat substitute; physicochemical characteristic; sensory evaluation

\section{Introduction}

Harbin dry sausage is characterised by its unique texture and flavour and is the most popular traditional fermented meat product in Northeast China [1]. The sausage is typically prepared by cube pork back-fat meat and lean meat mixed with spices, stuffed in casings and fermented for 4-7 days in a chamber at constant temperature and humidity. The average pork back-fat content in the dry sausages can be as high as $30 \%$ by the end of the fermentation process. It is generally known that animal fats confer favourable quality and acceptability properties (such as aroma, texture and mouthfeel) to fermented dry sausages [2]. However, research has proven that excessive fat intake is the main reason for an increased risk of cardiovascular and cerebrovascular diseases, obesity and some types of cancer [3-5]. Dietary guidelines prepared by the World Health Organization [6] state that consumers need to be aware of the dangers of excessive fat intake and daily fat intake should not exceed $30 \%$ of the total calories. The Chinese government has also implemented a series of strategies to protect consumers' health. For instance, the "Chinese Dietary Guidelines" suggest that daily fat intake should be between 20 and 25\% of the 
total calories [7]. Thus, it is necessary to reduce the pork back-fat content of Harbin dry sausages to ensure the healthy diet of consumers.

Reducing the fat content in fermented dry sausages is an enormous challenge faced by meat product industries worldwide. The most direct method and the method proposed by the meat products industry and governments is to reduce the fat addition level. Nevertheless, directly reducing the added fat is not feasible in fermented dry sausage products, because, quite apart from its economic value and nutritional contribution, the quality and acceptability properties (e.g., flavour, texture, mouthfeel) of the dry sausages will also be damaged [2]. Muguerza et al. [8] showed that reducing the fat level could increase the weight loss, hardness and firmness of fermented dry sausages and cause them to appear darker and redder. Liaros et al. [9] indicated that directly reducing the fat level from 30\% to $10 \%$ could induce case hardening, deteriorate the external appearance and increase the lipid oxidation of dry sausages. Olivares et al. [10] also stated that excessive fat reduction in fermented dry sausages could affect the texture by increasing the chewiness and hardness and deteriorating the sensory acceptability.

Several studies have attempted to overcome these issues by using plant-based ingredients formed from vegetable oils and typical neutral polysaccharide gels (such as konjac gel, carrageenan, carboxymethylcellulose, Jerusalem artichoke powder, locust bean gum and xanthan gum) to partially reduce the fat content in these meat products $[2,11,12]$. The plant-based ingredients are rich in dietary fibre and have no caloric value, which is more conducive to the health of consumers [13]. Using the plant-based ingredients instead of animal fat may be beneficial for resource-intensive meat product manufacturers to reduce the environmental problems. More importantly, the plant-based ingredients own a high water-retention capacity that can facilitate the regular moisture release occurring during the fermentation process, ensuring the sensory properties of fermented dry sausages [14]. Alejandre et al. [15] concluded that replacing fat with a carrageenan gel resulted in fermented dry sausages with similar taste and juiciness to the traditional ones, without inducing oxidation problems. Jiménez-Colmenero et al. [16] indicated that the appearance, flavour and juiciness were acceptable in low-fat fermented dry sausages prepared with appropriate levels of a konjac gel matrix. Additionally, the gelatinous substitutes can be shaped into cubes and provide the appearance of the visible fat cubes required for use as a raw material to replace animal fats [17].

Konjac glucomannan is a neutral polysaccharide extracted from Amorphophallus konjac, a native plant of East Asia. Several studies have proved that it forms gels that, combined with carrageenan, can be successfully used as 'fat analogues' in the formulation of lowfat meat products [2]. Moreover, in our previous study, the best physicochemical and sensory properties were found in the gel cube fat substitutes (CFS) prepared with konjac glucomannan and $\mathrm{k}$-carrageenan, and the CFS conferred sensory properties of juiciness and texture similar to that of fat [18]. Based on these results, the objective of this current study is to explore the effect of CFS as a fat replacer (at 20,40,60 and 80\% back-fat replacement) on the physicochemical and sensory characteristics of low-fat Harbin dry sausages. The moisture content, water activity $\left(a_{\mathrm{w}}\right), \mathrm{pH}$, thiobarbituric acid-reactive substances (TBARS), colour, texture profile analysis (TPA), electronic nose (E-nose) and sensory evaluation were analysed. Additionally, hierarchical cluster analysis (HCA) was performed among all the physicochemical characteristics of the dry sausages to identify similarities and differences among the sausages with or without CFS.

\section{Materials and Methods}

\subsection{Materials}

Fresh pork lean-meat and back-fat were obtained from the Carrefour supermarket (Harbin, China) and transported on ice to the meat science laboratory, although some research involving human or animal participants usually requires ethical approval, this protection is not extended to farmed animals. The visible fat and connective tissue on the lean pork were removed. The ingredients used to prepare CFS included corn germ 
oil (COFCO Co., Ltd., Harbin, Heilongjiang, China), konjac flour (glucomannan 83\%, 120 mesh; Johnson Konjac Technology Co., Ltd., Wuhan, Hubei, China), k-carrageenan flour (Jingxie Marine Technology Co., Ltd., Jinan, Shandong, China), barley $\beta$-glucan (Yuwei Biotechnology Co., Ltd., Beijing, China) and food-grade $\mathrm{Na}_{2} \mathrm{CO}_{3}$ (Zhenlemen Food Co., Ltd., Xuzhou, Jiangsu, China). Other additives, such as $\mathrm{NaCl}$, sodium nitrite and flavouring, were also purchased from the Carrefour supermarket.

\subsection{CFS Preparation}

The CFS was prepared according to the method of Ruiz-Capillas et al. [2] with slight modifications. Briefly, $4.5 \mathrm{~g}$ of konjac flour, $4.5 \mathrm{~g}$ of $\mathrm{k}$-carrageenan flour and $5.0 \mathrm{~g}$ of barley $\beta$-glucan were mixed in $76.0 \mathrm{~g}$ of water, then stirred at a speed of $1500 \mathrm{rpm}$ for $6 \mathrm{~min}$ using a stirrer (OS-Pro, KeXing Co., Ltd., Shanghai, China) with a 5 min intermittence time. After that, $10.0 \mathrm{~g}$ of corn germ oil was added to the mixture and stirred at $3000 \mathrm{rpm}$ for $3 \mathrm{~min}$. Then, $10.0 \mathrm{~mL}$ of $3.0 \%(w / v) \mathrm{Na}_{2} \mathrm{CO}_{3}$ solution was added to the mixture and stirred again under the same conditions. Finally, the mixture was placed in a suitable container to form CFS. The container was covered and manually compacted to remove air and then heated at $90{ }^{\circ} \mathrm{C}$ in a water bath for $60 \mathrm{~min}$. The prepared CFS was stored at $4{ }^{\circ} \mathrm{C}$ until use.

\subsection{Harbin Dry Sausage Preparation}

The Harbin dry sausages were prepared according to the process described by Chen et al. [19] with slight modifications. Five different formulations of the dry sausages were prepared, as shown in Table 1, including a control group without CFS and the following four low-fat samples: FS1 (80\% back-fat, 20\% CFS), FS2 (60\% back-fat, 40\% CFS), FS3 ( $40 \%$ back-fat, $60 \%$ CFS) and FS4 (20\% back-fat, $80 \%$ CFS). The sausage samples of each treatment were pre-dried at $40 \pm 2{ }^{\circ} \mathrm{C}$ for $24 \mathrm{~h}$ and then transferred to an incubator for fermentation $\left(25 \pm 2{ }^{\circ} \mathrm{C}, 75-80 \%\right.$ relative humidity). The sausage samples of each treatment were analysed at the designated fermentation times (day 0, 1, 4 and 7).

Table 1. Formulation $(\mathrm{g} / \mathrm{kg})$ of Harbin dry fermented sausages.

\begin{tabular}{cccc}
\hline Treatments & Lean Meat & Back Fat & CFS \\
\hline Control & 900 & 100 & - \\
FS1 & 900 & 80 & 20 \\
FS2 & 900 & 60 & 40 \\
FS3 & 900 & 40 & 60 \\
FS4 & 900 & 20 & 80 \\
\hline
\end{tabular}

Control, the dry fermented sausages without CFS; FS1-FS4, the dry fermented sausages containing different replacement levels of CFS $(20,40,60$ and $80 \mathrm{~g} / \mathrm{kg})$.

\subsection{Moisture Content and $a_{w}$}

Moisture content was determined using the method of the AOAC [20]. Measurements of $a_{\mathrm{W}}$ were obtained using a water activity meter (Decagon Devices, Seattle, WA, USA), as described by Chen et al. [21].

\section{5. $p H$ and TBARS Values}

The $\mathrm{pH}$ was determined according to the method of Sun et al. [22] with slight modifications. Briefly, the casing of the sausage sample was stripped, and approximately $10.0 \mathrm{~g}$ of sausage was stirred in $90.0 \mathrm{~mL}$ of distilled water at a speed of $500 \mathrm{rpm}$ for $5 \mathrm{~min}$ using a stirrer (OS-Pro, KeXing Co., Ltd., Shanghai, China). The $\mathrm{pH}$ of the slurry was measured using a standard $\mathrm{pH}$ meter (Mettler Toledo Instruments Co., Ltd., Shanghai, China) at room temperature $\left(25^{\circ} \mathrm{C}\right)$.

Lipid oxidation was evaluated by measuring the TBARS using the method of Wen et al. [23]. Briefly, $2.0 \mathrm{~g}$ of minced sausage samples were weighed and mixed with $3.0 \mathrm{~mL}$ of thiobarbituric acid, followed by an addition of $17.0 \mathrm{~mL} 2.5 \%$ trichloroacetic acid. Then, the mixture was heated in boiling water for $30 \mathrm{~min}$ and cooled at room temperature. 
After that, $4.0 \mathrm{~mL}$ of suspension was mixed with the same volume of chloroform, and then centrifuged at $1800 \times g$ for $10 \mathrm{~min}$. The supernatant was determined at $532 \mathrm{~nm}$. Results were expressed as milligrams of malonaldehyde (MDA) per kilogram of sausage, and calculated using the following equation:

$$
\operatorname{TBARS}(\mathrm{mg} / \mathrm{kg})=A_{532} / \omega \times 9.48
$$

where, among the equation, $A_{532}$ is the absorbance (532 nm) of the assay solution, $\omega$ is the sample weight $(\mathrm{g})$ and ' 9.48 ' is a constant derived from the dilution factor and the molar extinction coefficient $\left(152,000 \mathrm{M}^{-1} \mathrm{~cm}^{-1}\right)$ of the red thiobarbituric acid reaction product.

\subsection{Colour Measurement}

Instrumental colour was evaluated using the method of Chen et al. [5]. The samples of each treatment were maintained at $25{ }^{\circ} \mathrm{C}$ for $30 \mathrm{~min}$ and then sliced into approximately 2.0-centimeter-thick pieces. Colour values for the CIE colour coordinates $L^{*}$ (lightness), $a^{*}$ (redness) and $b^{*}$ (yellowness) were measured using a ZE-6000 colourimeter (Nippon Denshoku, Kogyo Co., Tokyo, Japan).

\subsection{Texture Profile Analysis}

The TPA of the sausage samples was measured at $25^{\circ} \mathrm{C}$ based on the method of Yin et al. [24] using a TA.XT2 plus Texture Analyser (Stable Micro Systems Ltd., Godalming, Surrey, UK) with a P-50 cylindrical probe. Four indexes were determined, including hardness $(\mathrm{N})$, chewiness $(\mathrm{N})$, springiness and resilience.

\subsection{E-Nose Analysis}

E-nose analysis was performed using the method of Yin et al. [25] using a PEN3 E-nose (Airsense Analytics GmbH, Schwerin, Germany). The information of 10 sensors for the E-nose is shown in Table 2.

Table 2. Information of 10 sensors for electronic nose.

\begin{tabular}{ccc}
\hline Sensors & Representative Material Species & Description \\
\hline W1 C & Aromatic compounds & Sensitive to aromatic constituents, benzenes \\
W5 S & Broad range & Sensitive to nitrogen oxides \\
W3 C & Aromatic & Sensitive to aroma, ammonia \\
W6 S & Hydrogen & Sensitive to hydrides \\
W5 C & Arom-aliph & Sensitive to short-chain alkane \\
W1 S & Broad-methane & aromatic components \\
W1 W & Sulphur-organic & Sensitive to methyl compounds \\
W2 S & Broad-alcohol & Sensitive to sulphides \\
W2 W & Sulph-chlor & Sensitive to alcohols, aldehydes and ketones \\
W3 S & Methane-aliph & Sensitive to organic sulphides \\
\end{tabular}

\subsection{Sensory Analysis}

This study was registered and approved by the Ethics in Research Committee of Northeast Agricultural University (Harbin, China). The procedure for sensory evaluation was adopted from Kong et al. [26] with some modifications. Thirty sensory analysis panellists (15 females and 15 males) were selected in the meat science laboratory of Northeast Agricultural University due to their experience in the sensory evaluation of meat products. All of the panellists signed a consent form agreeing to participate as volunteers in the sensory analysis. Before the sensory evaluation, the experts from the meat science laboratory of Northeast Agricultural University conducted three preliminary, sample familiarisation training sessions for the 30 panellists, and a "warm-up" sample (cooked dry sausage slices) was submitted to every panellist to evaluate each sensory trait. Afterwards, the steamed sausage samples of each treatment were sliced into approximately 
2-millimeter-thick pieces to begin the evaluation. The procedures of the sensory analysis were implemented according to a seven-point scale method [27] and carried out in a sensory laboratory designed in accordance with International Standard Organisation (ISO) [28]. Samples were evaluated for colour $(1=$ dark and dull, $7=$ red and shiny $)$, texture $(1=$ loose, $7=$ compact $)$, juiciness $(1=$ dry, $7=$ juicy $)$, firmness $(1=$ very hard, $7=$ very soft $)$, flavour ( 1 = extremely undesirable, $7=$ extremely desirable $)$ and acceptability $(1=$ low, $7=$ high $)$. Additionally, images of the different treatments, including uncooked sausages, cooked sausages and slices of cooked sausages containing true fat and CFS, were captured using a digital camera under the same conditions.

\subsection{Statistical Analysis}

All experiments were implemented in triplicate (triplicate observations) for each batch of sausages. Data were analysed using the General Linear Models procedure of Statistix 8.1 (Analytical Software, Saint Paul, MN, USA) and displayed as the mean \pm standard error (SE). One-way analysis of variance (ANOVA) was used to assess the significance of the main effects $(p<0.05)$ between means using Tukey's multiple comparison test. Figures were drawn using the Sigma Plot 13 software (Systat Software GmbH, San Jose, CA, USA). Three independent batches of sausages (replicates) were prepared. Principal component analysis (PCA) was performed among the treatments and sensors of E-nose analysis using SPSS Statistics version 22.0 (Analytical Software, New York, NY, USA). In addition, hierarchical cluster analysis (HCA) was performed among all physicochemical characteristics (moisture content, $a_{\mathrm{w}}, \mathrm{pH}, \mathrm{TBARS}$ values, colour and TPA) of the dry sausages by using R software (version 3.6.3; Tsinghua University, Beijing, China) to identify similarities and differences among the sausages with or without CFS.

\section{Results and Discussion}

\subsection{Moisture Content and $a_{w}$}

The moisture content and $a_{\mathrm{w}}$ gradually decreased in all the treatments during the 7-day fermentation process, as shown in Table 3. The initial moisture content was higher in all the treatment samples (FS1-FS4) than in the control $(p<0.05)$, and FS4 (with $80 \%$ CFS) recorded the highest moisture content $(p<0.05)$, perhaps due to the higher moisture content of the CFS than the back-fat. However, at the end of the pre-drying stage $(24 \mathrm{~h})$, all the treatment samples displayed a significantly lower moisture content compared to the control $(p<0.05)$. This moisture loss during pre-drying could be related to the high temperature $\left(40{ }^{\circ} \mathrm{C}\right)$ accelerating the moisture evaporation [10].

Table 3. Changes in moisture content (\%) and water activity $\left(a_{\mathrm{w}}\right)$ of Harbin dry sausages with different replacement levels of CFS during fermentation.

\begin{tabular}{cccccc}
\hline \multirow{5}{*}{} & \multicolumn{4}{c}{ Fermentation Time (d) } \\
\cline { 2 - 5 } & & $\mathbf{0}$ & $\mathbf{1}$ & $\mathbf{4}$ & $\mathbf{7}$ \\
\hline moisture & Control & $62.52 \pm 0.05^{\mathrm{Ad}}$ & $53.39 \pm 0.32^{\mathrm{Ba}}$ & $38.37 \pm 0.38^{\mathrm{Ca}}$ & $28.57 \pm 0.45^{\mathrm{Da}}$ \\
content & FS2 & $63.32 \pm 0.38^{\mathrm{Ac}}$ & $52.06 \pm 0.28^{\mathrm{Bb}}$ & $37.12 \pm 0.31^{\mathrm{Ca}}$ & $27.31 \pm 0.34^{\mathrm{Da}}$ \\
$(\%)$ & FS3 & $64.35 \pm 0.25^{\mathrm{Ab}}$ & $50.50 \pm 0.38^{\mathrm{Bc}}$ & $35.63 \pm 0.43^{\mathrm{Cb}}$ & $27.55 \pm 0.39^{\mathrm{Da}}$ \\
& FS4 & $65.53 \pm 0.18^{\mathrm{Aa}}$ & $47.35 \pm 0.31^{\mathrm{Bd}}$ & $32.64 \pm 0.35^{\mathrm{Cc}}$ & $24.36 \pm 0.64^{\mathrm{Db}}$ \\
& Control & $0.95 \pm 0.01^{\mathrm{Ab}}$ & $0.92 \pm 0.01^{\mathrm{Ba}}$ & $0.87 \pm 0.01^{\mathrm{Ca}}$ & $0.84 \pm 0.01^{\mathrm{Da}}$ \\
water & FS1 & $0.96 \pm 0.01^{\mathrm{Aab}}$ & $0.90 \pm 0.01^{\mathrm{Bb}}$ & $0.86 \pm 0.01^{\mathrm{Ca}}$ & $0.82 \pm 0.01^{\mathrm{Db}}$ \\
activity & FS2 & $0.96 \pm 0.01^{\mathrm{Aa}}$ & $0.91 \pm 0.01^{\mathrm{Bb}}$ & $0.84 \pm 0.01^{\mathrm{Cb}}$ & $0.81 \pm 0.01^{\mathrm{Db}}$ \\
& FS3 & $0.96 \pm 0.01^{\mathrm{Aa}}$ & $0.90 \pm 0.01^{\mathrm{Bbc}}$ & $0.83 \pm 0.01^{\mathrm{Cc}}$ & $0.79 \pm 0.01^{\mathrm{Dc}}$ \\
& FS4 & $0.97 \pm 0.01^{\mathrm{Aa}}$ & $0.90 \pm 0.01^{\mathrm{Bc}}$ & $0.80 \pm 0.01^{\mathrm{Cd}}$ & $0.78 \pm 0.01 \mathrm{Dd}$ \\
\hline
\end{tabular}

$\overline{\mathrm{a}-\mathrm{d}}$ Means within the same column for the same index with different lowercase letters differ significantly among the treatments $(p<0.05)$. A-D Means within the same row with different uppercase letters differ significantly among different fermentation times $(p<0.05)$. Control: 100\% backfat; FS1: $80 \%$ backfat and 20\% CFS; FS2: $60 \%$ backfat and $40 \%$ CFS; FS3: $40 \%$ backfat and 60\% CFS; FS4: 20\% backfat and $80 \%$ CFS. 
After pre-drying, all the samples were fermented, during which further decreases in the moisture content occurred. At the end of fermentation ( 7 days), the moisture content had decreased from $62.52,63.32,64.35,64.88$ and $65.53 \%$ to $28.57,27.31,27.55,24.36$ and $22.06 \%$ in the control, FS1, FS2, FS3 and FS4 samples, respectively $(p<0.05)$. At this point, there was no significant difference among the control, FS1 and FS2 treatments $(p>0.05)$, but the FS3 and FS4 treatments had a significantly lower moisture content compared to the control $(p<0.05)$. The water holding capacity of the CFS is mainly related to the gel structure, which might have steadily worsened throughout the fermentation process, inducing a lower moisture content in the treatment samples with higher fat replacement levels $(60 \%$ and $80 \%)$ [29]. The same results were also reported in low-fat dry fermented sausages amended with gelatinous substances $[2,17]$. Moreover, the water loss could not induce degradation of CFS in the fermentation process of dry fermented sausages, which means that it could potentially be used in non-fermented sausages.

The initial (day 0) $a_{\mathrm{w}}$ values were higher in the back-fat-reduced samples than in the control group $(p<0.05)$. All the samples showed a gradual decrease in $a_{\mathrm{w}}$ during the fermentation stage, reaching $0.84,0.82,0.81,0.79$ and 0.78 in the control, FS1, FS2, FS3 and FS4, respectively $(p<0.05)$, by the end of the fermentation process ( 7 days). The $a_{\mathrm{w}}$ of all the FS treatments was significantly lower than that of the control group at day 7 , especially of the FS3 and FS4 treatments $(p<0.05)$. Although there was no linear correlation between moisture content and $a_{\mathrm{W}}$, both indexes showed a similar change trend [30]. The $a_{\mathrm{W}}$ is a colligative property that reflects the water state, mainly the amount of free (unbound) water. The lower the $a_{\mathrm{w}}$ is, the higher the degree of binding is. On the one hand, the texture of the dry sausages became more compact during the fermentation process, which may cause a higher degree of moisture-binding. On the other hand, the lower $a_{\mathrm{w}}$ in the FS3 and FS4 treatments could be related to higher moisture evaporation [9]. Similar changes in the $a_{\mathrm{w}}$ of dry fermented sausage have been reported by García et al. [31] and Mendoza et al. [32].

\section{2. $p H$ and TBARS Values}

A rapid $\mathrm{pH}$ decline at the beginning of the fermentation stage is a typical characteristic of dry fermentation meat products that confers the unique flavour and enhances the quality of the product [33]. The $\mathrm{pH}$ changes of the dry sausages during the 7-day fermentation are shown in Figure 1. All the treatment samples exhibited a progressive decline in the $\mathrm{pH}$ throughout the fermentation stage. At day 0 , the $\mathrm{pH}$ was higher in the reduced-back-fat samples than in the control group $(p<0.05)$, and it seemed that the higher the proportion of CFS in the dry sausages is, the higher the $\mathrm{pH}$ of the sample is, probably due to the higher $\mathrm{pH}$ of the CFS compared to that of the back-fat. As fermentation progressed, the $\mathrm{pH}$ of all the treatments rapidly dropped during the first few days and then decreased smoothly until the end of the fermentation process (day 7). It was notable that the highest $\mathrm{pH}$ was found in the FS4 treatment $(p<0.05)$ and was comparable to that of the FS3 treatment $(p>0.05)$. An excessively high $\mathrm{pH}$ is not a typical technical characteristic of Harbin dry sausages and could negatively affect consumer acceptability.

The TBARS are a reliable indicator of lipid oxidation in meat products that reflects the level of secondary oxidation products, such as malondialdehyde, aldehydes and ketones [34]. The TBARS data for all the treatments are presented in Figure 2. All the TBARS values were comparable at day $0(p<0.05)$ and sharply increased from day 0 to day 7 , especially in the control group, which reached a final value of $0.96 \mathrm{mg} \mathrm{MDA} / \mathrm{kg}(p<0.05)$ that was significantly higher than the other groups. Its higher TBARS value could be attributed to its higher fat content. However, Trik et al. [35] mentioned that, compared to back-fat, the healthier vegetable oil in the konjac matrix substitute could increase the TBARS value of the dry sausages because of the high quantities of unsaturated (particularly polyunsaturated) fatty acids in the oil. Contrary to this outcome, we prepared CFS using commercial corn germ oil containing a natural antioxidant tocopherol, which protects against oxidation. Valencia et al. [36] claimed that there was no obvious lipid oxidation in dry fermented sausages enriched with fish oil and synthetic antioxidants (butylated hydroxytoluene or 
butylated hydroxyanisole). The same result was found in Dutch-style low-fat fermented sausages prepared using commercial fish oil instead of pork back-fat [37].

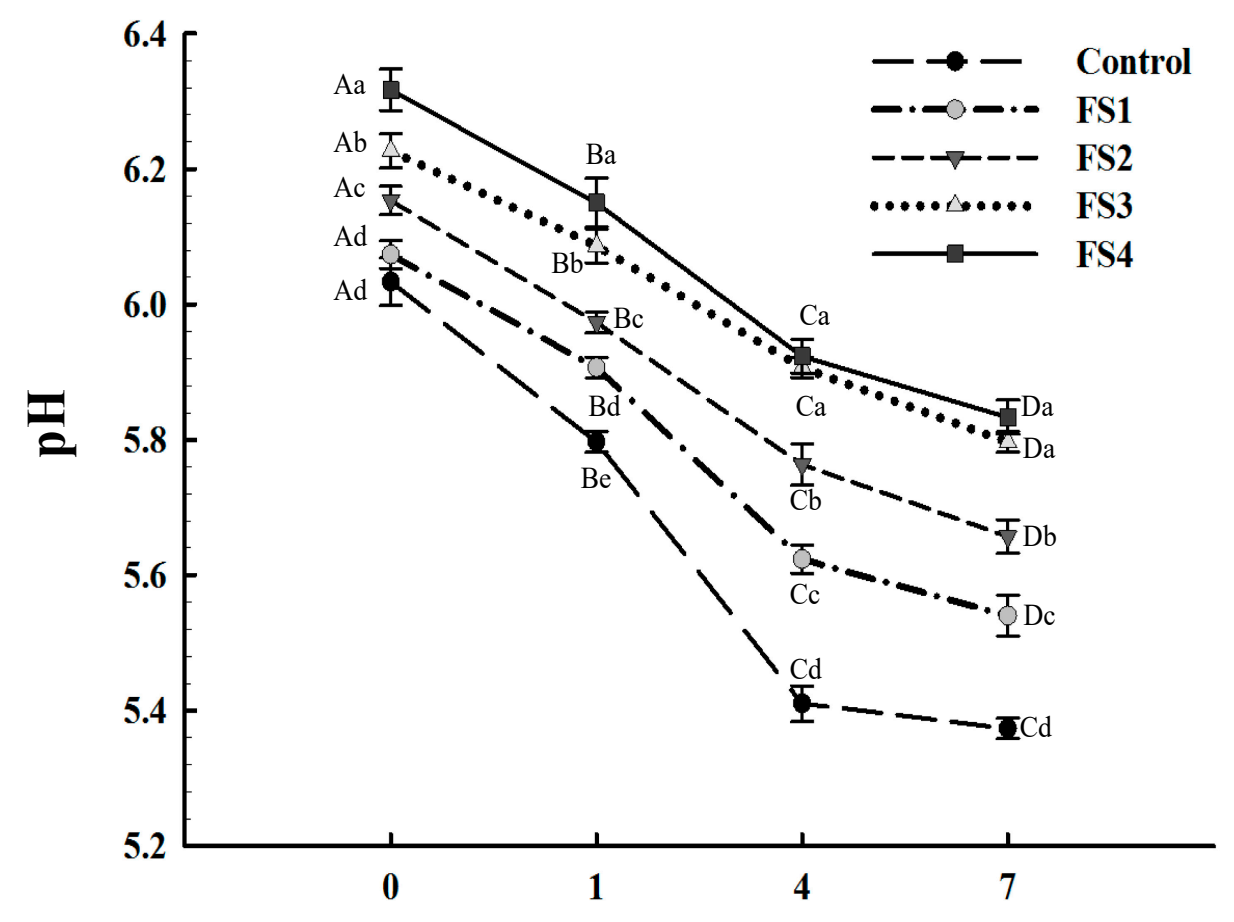

Fermentation time (d)

Figure 1. Changes in $\mathrm{pH}$ of Harbin dry sausages with different replacement levels of CFS during fermentation. Control: 100\% backfat; FS1: 80\% backfat and 20\% CFS; FS2: $60 \%$ backfat and 40\% CFS; FS3: $40 \%$ backfat and 60\% CFS; FS4: 20\% backfat and 80\% CFS. Different lowercase letters (a-d) mean significant differences among the treatments $(p<0.05)$. Different uppercase letters $(\mathrm{A}-\mathrm{D})$ mean significant differences among different fermentation times $(p<0.05)$.

\subsection{Colour Analysis}

Colour is a useful indicator of the quality of meat products, particularly dry fermented sausages, and it often affects consumers' purchase desire [38]. The colour coordinates $L^{*}$, $a^{*}$ and $b^{*}$ are presented in Table 4 . There was a gradual decrease in lightness $\left(L^{*}\right)$ but an increase in redness $\left(a^{*}\right)$ and yellowness $\left(b^{*}\right)$ for all the samples during the fermentation stage $(p<0.05)$. At the end of fermentation ( 7 days), $L^{*}$ was similar between the control group and FS1 treatment $(p>0.05)$ and lowest in the FS4 treatment $(p<0.05)$. This result may be attributed to the continuous water loss during fermentation, causing the colour of the sausages to darken [10]. It was also notable that the FS3 and FS4 treatments, with higher fat replacement levels, had the highest $b^{*}$ among the samples during the fermentation stage $(p<0.05)$. On the one hand, lipid oxidation may have contributed to the increase in $b^{*}$. Liu et al. [39] found a close association between $b^{*}$ and the yellow pigment produced by the reaction of lipid oxidation products with the amine in protein or phospholipid head groups. On the other hand, it is noteworthy that CFS is more yellow than true backfat, which may also explain the comparatively higher $b^{*}$ in the FS3 and FS4 treatments. Additionally, the FS3 and FS4 treatments had a higher $a^{*}$ relative to the control group at day $7(p<0.05)$. Similar results were found in Spanish dry fermented sausages and dry ripened sausages $[15,40]$. 


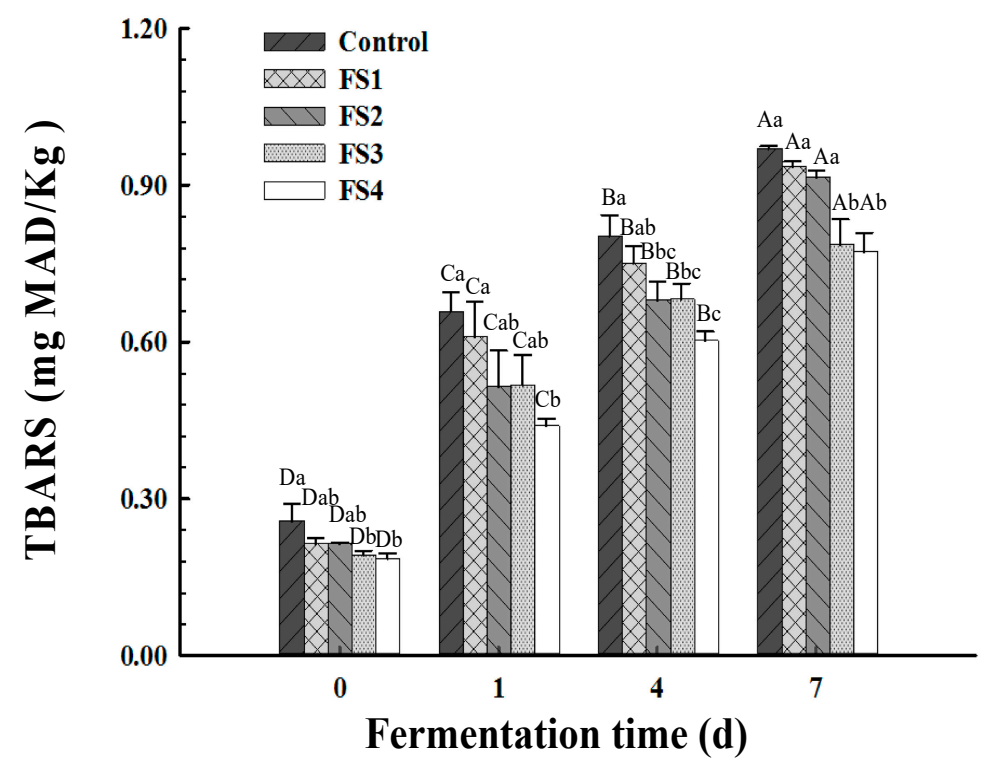

Figure 2. Changes in thiobarbituric acid reactive substance (TBARS) values of Harbin dry sausages with different replacement levels of CFS during fermentation. Control: 100\% backfat; FS1: $80 \%$ backfat and 20\% CFS; FS2: $60 \%$ backfat and 40\% CFS; FS3: $40 \%$ backfat and 60\% CFS; FS4: $20 \%$ backfat and $80 \%$ CFS. Different lowercase letters (a-c) mean significant differences among the treatments $(p<0.05)$. Different uppercase letters $(A-D)$ mean significant differences among different fermentation times $(p<0.05)$.

Table 4. Changes in colour values $\left(L^{*}, a^{*}\right.$ and $\left.b^{*}\right)$ of Harbin dry sausages with different replacement levels of CFS during fermentation.

\begin{tabular}{|c|c|c|c|c|c|}
\hline & & \multicolumn{4}{|c|}{ Fermentation Time (d) } \\
\hline & & 0 & 1 & 4 & 7 \\
\hline \multirow{5}{*}{$L^{*}$-value } & Control & $61.30 \pm 1.01 \mathrm{Aa}$ & $50.42 \pm 0.71 \mathrm{Ba}$ & $37.51 \pm 1.29 \mathrm{Ca}$ & $31.74 \pm 0.61^{\mathrm{Da}}$ \\
\hline & FS1 & $60.91 \pm 0.70^{\mathrm{Aa}}$ & $47.03 \pm 0.25^{\mathrm{Bb}}$ & $33.58 \pm 0.71^{\mathrm{Cb}}$ & $31.71 \pm 0.36^{\mathrm{Da}}$ \\
\hline & FS2 & $60.58 \pm 0.54 \mathrm{Aa}$ & $45.68 \pm 0.21^{\mathrm{Bc}}$ & $32.54 \pm 0.62 \mathrm{Cbc}$ & $29.92 \pm 0.58^{\mathrm{Db}}$ \\
\hline & FS3 & $60.69 \pm 0.60^{\mathrm{Aa}}$ & $43.68 \pm 0.16^{\mathrm{Bd}}$ & $30.40 \pm 0.82 \mathrm{Ccd}$ & $28.59 \pm 0.66^{\mathrm{Db}}$ \\
\hline & FS4 & $60.28 \pm 0.39$ Аa & $43.27 \pm 0.18^{\mathrm{Bd}}$ & $29.49 \pm 0.46^{\mathrm{Cd}}$ & $26.81 \pm 0.51 \mathrm{Dc}$ \\
\hline \multirow{5}{*}{$a^{*}$-value } & Control & $10.11 \pm 0.04^{\mathrm{Cd}}$ & $12.84 \pm 0.04^{\mathrm{Bb}}$ & $14.13 \pm 0.14^{\mathrm{Ac}}$ & $14.42 \pm 0.12 \mathrm{Ac}$ \\
\hline & FS1 & $10.23 \pm 0.05^{\mathrm{Cd}}$ & $13.04 \pm 0.10^{\mathrm{Bb}}$ & $14.29 \pm 0.13^{\mathrm{Ac}}$ & $14.43 \pm 0.22 \mathrm{Ac}$ \\
\hline & FS2 & $10.52 \pm 0.14^{C_{c}}$ & $13.41 \pm 0.49^{\mathrm{Bab}}$ & $14.77 \pm 0.11^{\mathrm{ABb}}$ & $14.96 \pm 0.07^{\mathrm{Ab}}$ \\
\hline & FS3 & $12.07 \pm 0.06^{\mathrm{Cb}}$ & $14.00 \pm 0.15^{\mathrm{Ba}}$ & $15.62 \pm 0.20 \mathrm{Aa}$ & $15.77 \pm 0.12 \mathrm{Aa}$ \\
\hline & FS4 & $12.34 \pm 0.04^{\mathrm{Ca}}$ & $13.97 \pm 0.05^{\mathrm{Ba}}$ & $15.84 \pm 0.14^{\mathrm{Aa}}$ & $15.95 \pm 0.10^{\mathrm{Aa}}$ \\
\hline \multirow{5}{*}{$b^{*}$-value } & Control & $14.04 \pm 0.10^{\mathrm{Cc}}$ & $14.07 \pm 0.28^{\mathrm{Cc}}$ & $14.28 \pm 0.12^{\mathrm{Bd}}$ & $14.88 \pm 0.03^{\mathrm{Ac}}$ \\
\hline & FS1 & $14.17 \pm 0.15^{\mathrm{Cbc}}$ & $14.15 \pm 0.17^{\mathrm{Cbc}}$ & $14.41 \pm 0.08^{\mathrm{Bc}}$ & $14.95 \pm 0.07^{\mathrm{Ac}}$ \\
\hline & FS2 & $14.26 \pm 0.23^{\mathrm{Cb}}$ & $14.31 \pm 0.20^{\mathrm{Cb}}$ & $14.66 \pm 0.18^{\mathrm{Bb}}$ & $15.13 \pm 0.12^{\mathrm{Ab}}$ \\
\hline & FS3 & $14.67 \pm 0.08^{\mathrm{Ca}}$ & $14.97 \pm 0.03^{\mathrm{Ba}}$ & $14.92 \pm 0.10^{\mathrm{Ba}}$ & $15.83 \pm 0.11 \mathrm{Aa}$ \\
\hline & FS4 & $14.64 \pm 0.22 \mathrm{Ca}$ & $14.96 \pm 0.13^{\mathrm{Ba}}$ & $14.86 \pm 0.04^{\mathrm{Ba}}$ & $15.67 \pm 0.23^{\mathrm{Aa}}$ \\
\hline
\end{tabular}

${ }^{a-d}$ Means within the same column for the same index with different lowercase letters differ significantly among the treatments $(p<0.05)$. A-D Means within the same row with different uppercase letters differ significantly among different fermentation times $(p<0.05)$. Control: 100\% backfat; FS1: $80 \%$ backfat and 20\% CFS; FS2: $60 \%$ backfat and $40 \%$ CFS; FS3: $40 \%$ backfat and $60 \%$ CFS; FS4: $20 \%$ backfat and $80 \%$ CFS.

\subsection{TPA}

The TPA of foods is a key indicator to simulate and understand their perceived textural characteristics. The instrumental texture properties obtained using TPA were hardness, chewiness, springiness and resilience, as shown in Table 5. The hardness and chewiness increased sharply in all the samples throughout the fermentation process $(p<0.05)$. These properties were comparable between the FS1 and FS2 treatments $(p>0.05)$ and highest in the FS4 treatment at day $7(p<0.05)$, perhaps due to the lower back-fat content and 
water content in the FS4 treatment. Water content mainly impacts the final texture of fermented sausages and is negatively related to the hardness [41]. CFS is a gelatinous material that has a high water content. As fermentation progressed, the water in the CFS gradually evaporated, increasing the hardness and chewiness of the FS treatments. Similar conclusions have been reported in fat-reduced non-acid fermented sausages and low-fat dry fermented sausages formulated with a konjac gel matrix [2,42]. The springiness and resilience of all the treatments had decreased significantly at the end of fermentation $(p<0.05)$. FS4 displayed the lowest springiness and resilience at day $7(p<0.05)$, producing an unsatisfactory texture quality.

Table 5. Changes in texture profile analysis (TPA) of Harbin dry sausages with different replacement levels of CFS during fermentation.

\begin{tabular}{|c|c|c|c|c|c|}
\hline Fermentation Time (d) & Treatments & Hardness (N) & Springiness & Chewiness (N) & Resilience \\
\hline \multirow{5}{*}{0} & Control & $13.61 \pm 1.07^{\mathrm{Ba}}$ & $0.63 \pm 0.02 \mathrm{Aa}$ & $4.45 \pm 0.37^{\mathrm{Ba}}$ & $0.23 \pm 0.01^{\mathrm{Aa}}$ \\
\hline & FS1 & $13.98 \pm 0.71^{\mathrm{Ba}}$ & $0.62 \pm 0.05$ Аа & $4.34 \pm 0.31 \mathrm{Ba}$ & $0.20 \pm 0.01 \mathrm{Aab}$ \\
\hline & FS2 & $12.71 \pm 0.68^{\mathrm{Bab}}$ & $0.61 \pm 0.06$ Aab & $4.15 \pm 0.22^{\mathrm{Bab}}$ & $0.19 \pm 0.01 \mathrm{Ab}$ \\
\hline & FS3 & $12.28 \pm 0.63^{\mathrm{Bab}}$ & $0.58 \pm 0.04 \mathrm{Ab}$ & $3.73 \pm 0.27^{\mathrm{Bb}}$ & $0.17 \pm 0.01 \mathrm{Ac}$ \\
\hline & FS4 & $11.16 \pm 0.84^{\mathrm{Bb}}$ & $0.58 \pm 0.05^{\mathrm{Ab}}$ & $3.47 \pm 0.17^{\mathrm{Bb}}$ & $0.16 \pm 0.01 \mathrm{Ad}$ \\
\hline \multirow{5}{*}{7} & Control & $60.73 \pm 1.17 \mathrm{Ac}$ & $0.59 \pm 0.04^{\mathrm{Ba}}$ & $17.99 \pm 0.13^{\mathrm{Ac}}$ & $0.17 \pm 0.01^{\mathrm{Ba}}$ \\
\hline & FS1 & $61.66 \pm 0.67^{\mathrm{Ac}}$ & $0.58 \pm 0.03^{\mathrm{Ba}}$ & $18.53 \pm 0.39 \mathrm{Ab}$ & $0.16 \pm 0.01 \mathrm{Ba}$ \\
\hline & FS2 & $63.17 \pm 1.16^{\mathrm{Abc}}$ & $0.56 \pm 0.04^{\mathrm{Bb}}$ & $18.65 \pm 0.53^{\mathrm{Ab}}$ & $0.16 \pm 0.01 \mathrm{Ba}$ \\
\hline & FS3 & $64.66 \pm 1.34$ Aab & $0.54 \pm 0.07^{\mathrm{Bc}}$ & $21.24 \pm 0.67 \mathrm{Aa}$ & $0.13 \pm 0.01^{\mathrm{Bb}}$ \\
\hline & FS4 & $67.34 \pm 0.95 \mathrm{Aa}$ & $0.55 \pm 0.05^{\mathrm{Bc}}$ & $22.32 \pm 0.41 \mathrm{Aa}$ & $0.11 \pm 0.01^{\mathrm{Bc}}$ \\
\hline
\end{tabular}

$\overline{a-d}$ Means within the same column for the same fermentation time with different lowercase letters differ significantly among the treatments $(p<0.05)$ A-B Means within the same column for the same treatment with different uppercase letters differ significantly among different fermentation times ( $p$ < 0.05). Control: 100\% backfat; FS1: 80\% backfat and 20\% CFS; FS2: $60 \%$ backfat and 40\% CFS; FS3: $40 \%$ backfat and $60 \%$ CFS; FS4: $20 \%$ backfat and $80 \%$ CFS.

\subsection{E-Nose Analysis}

E-nose is a powerful tool that has recently been widely used to distinguish odour profiles between different meat products, such as dry fermented sausages, smoked sausage and golden pompano $[25,43,44]$. A total of 10 gas sensors were set in the PEN3 system. These sensors were sensitive to aromatic benzenes (W1 C), nitrogen oxides (W5 S), ammonia (W3 C), hydrides (W6 S), short-chain alkane aromatic components (W5 C), methyl compounds (W1 S), sulphides (W1 W), organic sulphides (W2 W), long-chain alkanes (W3 S) and alcohols, aldehydes and ketones (W2 S). As shown in Figure 3A, the W6 S, W1 S and W2 $S$ sensors exhibited the strongest responses to volatile compounds in all the treatments, indicating that hydride constituents, methyl compounds, alcohols, aldehydes and ketones were formed during fermentation. The response values of the W6 S, W1 S and W2 S sensors decreased with the increasing levels of CFS $(p<0.05)$, suggesting that the higher fat replacement levels in the sausages might impede the formation of characteristic flavours.

The PCA loading plot of all the treatments and sensors are shown in Figure 3B. PC1 and PC2 explained $96.0 \%$ (83.9\% and $12.1 \%$, respectively) of the total variance. Therefore, it is considered that Figure 3B represents the majority of the information [45]. The PC1 spatial regions of each treatment indicated a cluster comprising FS1, FS2 and FS3, suggesting they shared similar flavours [44]. The control group was located to the right and the FS4 treatment was located to the left, both distant from the other samples. The results indicated that CFS could change the flavour of the dry fermented sausages, especially at an $80 \%$ fat replacement. The spatial distribution of the E-nose sensors is also shown in Figure 3B. The sensors W1 S, W2 S, W5 S, W6 S and W1 W contributed most to the control group, indicating that the corresponding flavour substances were dominant. In contrast, the sensors W3 C, W5 C and W2 W contributed most to the FS4 treatment, showing that ammonia, organic sulphides and short-chain alkane aromatic components were dominant. 
(A)
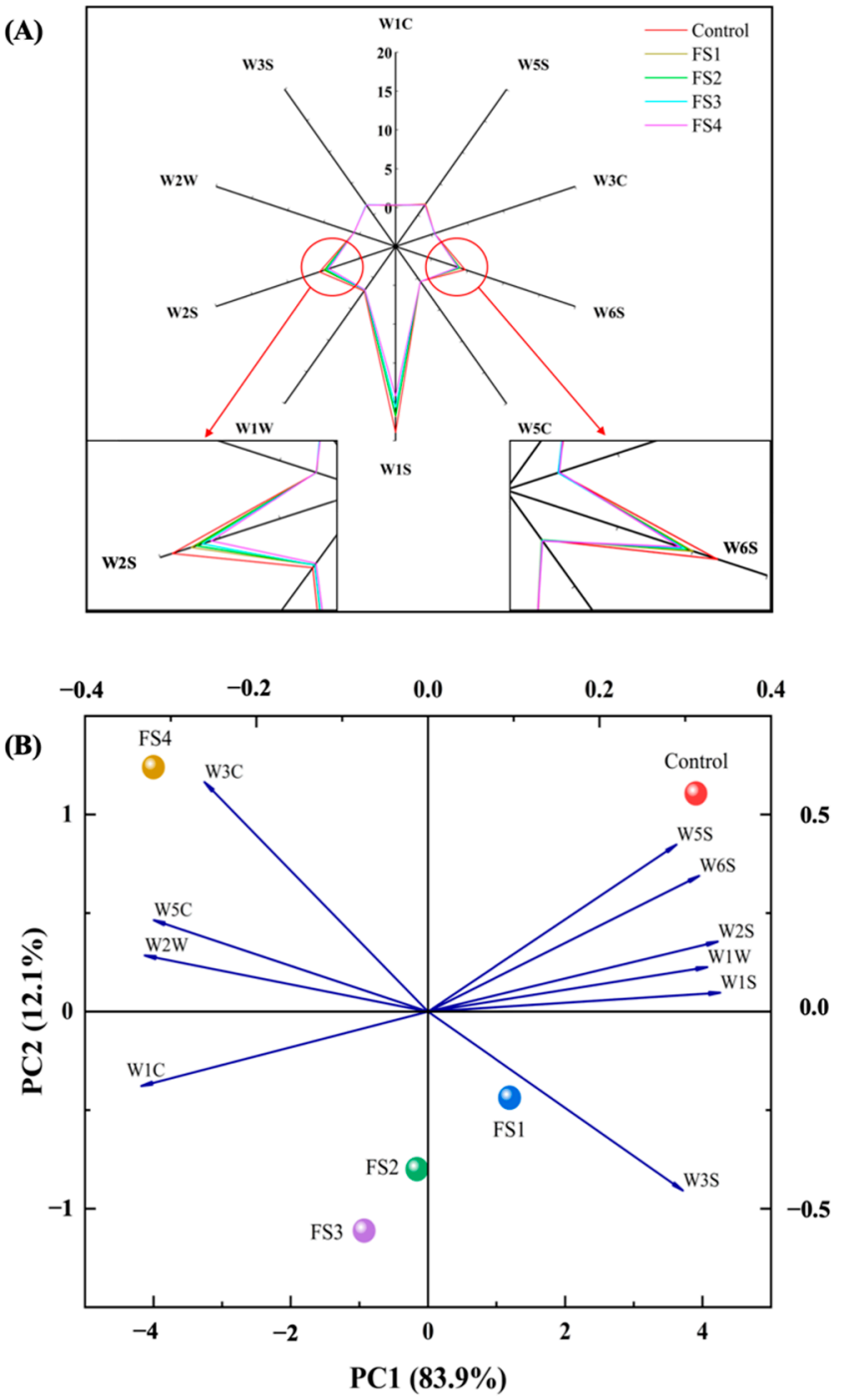

Figure 3. Radar chart of the electronic nose (E-nose) response data (A), principal component analysis loading plot of different treatments and sensors (B). Control: 100\% backfat; FS1: $80 \%$ backfat and 20\% CFS; FS2: $60 \%$ backfat and 40\% CFS; FS3: 40\% backfat and 60\% CFS; FS4: $20 \%$ backfat and $80 \%$ CFS.

\subsection{Sensory Analysis}

The sensory scores for all the envaulted attributes (colour, texture, juiciness, firmness, flavour and acceptability) and the appearance of the uncooked sausages, cooked sausages and slices of cooked sausages containing true back-fat and CFS are shown in Figures 4 and 5. Atypical appearances were observed in the sausages with high levels of CFS. First of all, the appearance of the sausages with high levels of CFS were more wrinkled and irregular than the others due to the lower moisture content at the end of fermentation. Moreover, the captured image of the uncooked sausages without or with lower levels of CFS presented more white true back-fat than the sausages with high levels of CFS, which highlighted the white appearance of true back-fat compared to CFS. The true back-fat was swollen and shiny after cooking, and the slices of cooked sausage containing true back-fat were relatively compact. It is noted that these atypical appearances (wrinkled appearance and white fat losing) presented in the sausages with high levels of CFS (FS3 and FS4) may lead to a significant reduction in the desire and appetite of consumers. The FS3 and FS4 treatments received the lowest scores for all the attributes $(p<0.05)$, demonstrating that excessive fat replacement may cause a noticeable deterioration of the sensory quality of 
the sausages. Moreover, consistent with the moisture content and $a_{\mathrm{w}}$ results, the excessive moisture evaporation led to the dryness and firmness of the FS3 and FS4 treatments [32].

\section{Juiciness}

Firmness
Texture

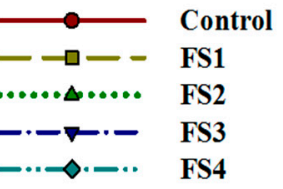

FS4

\section{Flavour}

Acceptability

Figure 4. Sensory evaluation of the Harbin dry sausages with different replacement levels of CFS after fermentation. Control: 100\% backfat; FS1: 80\% backfat and 20\% CFS; FS2: $60 \%$ backfat and 40\% CFS; FS3: 40\% backfat and 60\% CFS; FS4: 20\% backfat and 80\% CFS. Different uppercase letters $(\mathrm{A}-\mathrm{C})$ mean significant differences among the treatments $(p<0.05)$.

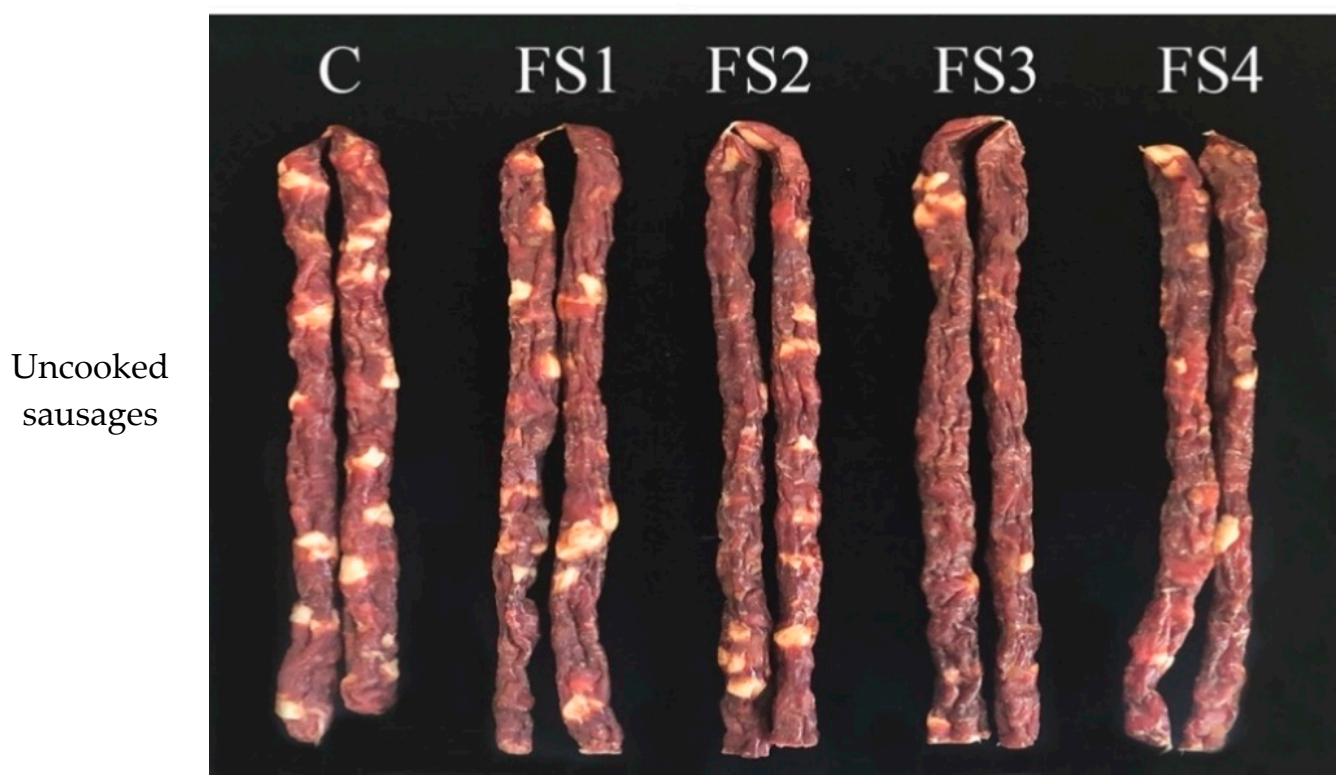

Figure 5. Cont. 


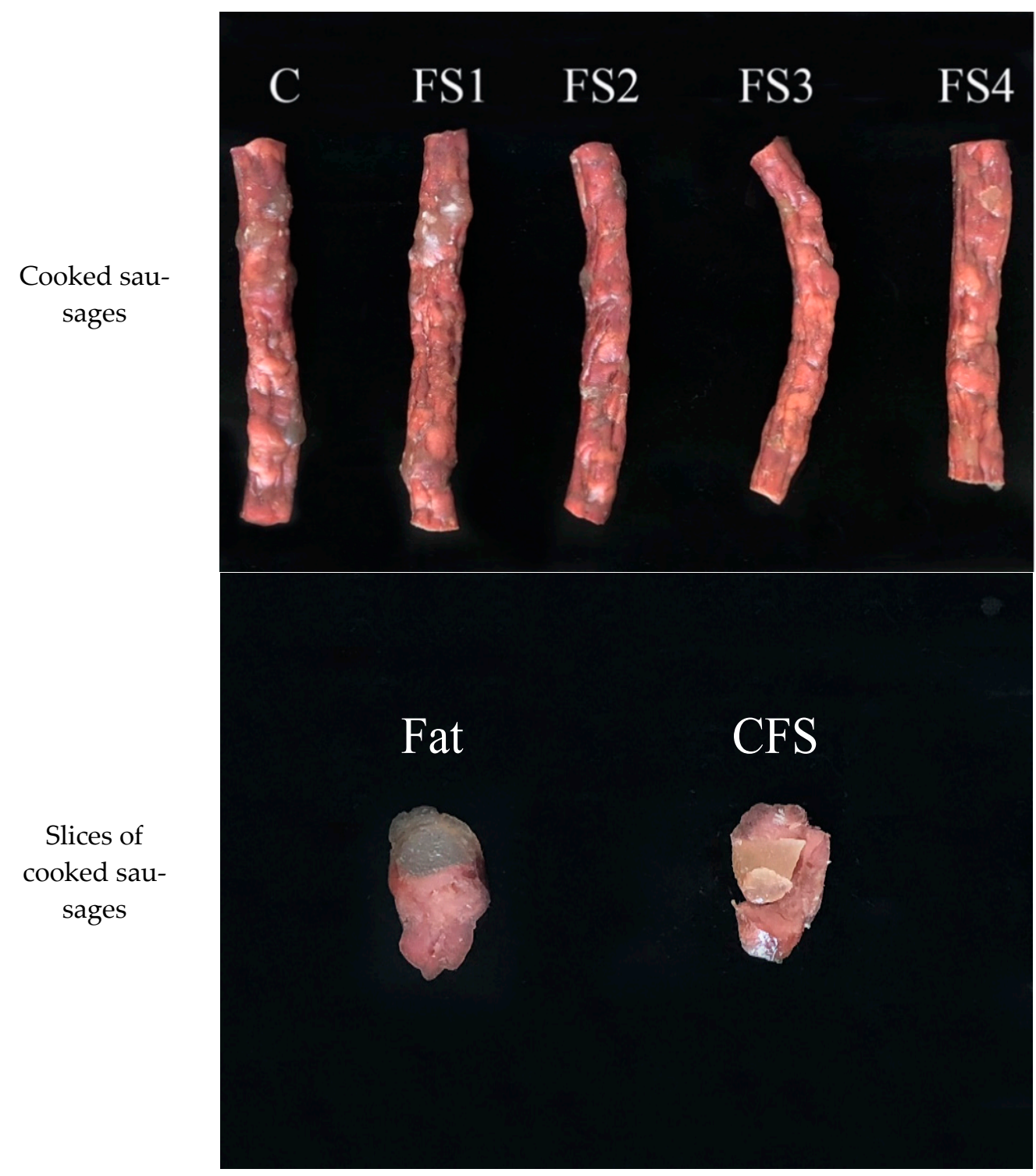

Figure 5. Appearance of the uncooked sausages, cooked sausages and slices of cooked sausages containing true fat and CFS.

The flavour of Harbin dry sausages is mainly affected by the type and quantity of ingredients. Flavour was comparable among the control, FS1 and FS2 treatments $(p>0.05)$. Therefore, if the level of fat replacement with CFS is controlled within a reasonable range, the flavour will not be remarkably affected. Similar results were reported by Liaros et al. [9].

The juiciness showed a similar behaviour to the flavour, and the lowest scores were contained for the FS4 treatment $(p<0.05)$. No differences were perceived among the control group, FS1 and FS2 treatments $(p>0.05)$. The higher juiciness scores mainly related to the cooked true back-fat. The lowest levels of true back-fat in FS3 and FS4 treatments caused a decrease in the perceived juiciness.

In general, the panellists deemed the FS3 and FS4 treatments limited by harder and drier meat systems compared with the control group. The FS1 and FS2 treatments had acceptable sensory characteristics, meaning that the upper limit of using CFS to replace pork back-fat in Harbin dry fermented sausages is $40 \%$. 


\subsection{HCA Analysis}

HCA is the most-used data visualisation tool to assess the multivariate association among treatment groups. The data are depicted in a heatmap in which the higher scores are in red and the lowers score in blue [46]. As shown in Figure 6, cluster one indicated that the control, FS1 and FS2 treatments were associated with high resilience, moisture content, $L^{*}$, TBARS value, springiness and $a_{\mathrm{w}}$, opposite to the FS3 and FS4 treatments. In cluster two, the evident downward trend of $b^{*}, a^{*}, \mathrm{pH}$, chewiness and hardness in the control, FS1 and FS2 treatments contrasted with the upward trend of these properties in the FS3 and FS4 treatments. These results showed that indicators in the same cluster had significant positive correlations with each other and were negatively correlated with those in different clusters. For instance, the higher moisture content in the sausages normally meant higher springiness and lower hardness. Notably, the FS1 and FS2 treatments were grouped with the control group, and the FS3 treatment was grouped with the FS4 treatment, which indicated that an excessive fat replacement with CFS might induce noticeable changes in the quality characteristics of traditional full-fat dry fermented sausages.

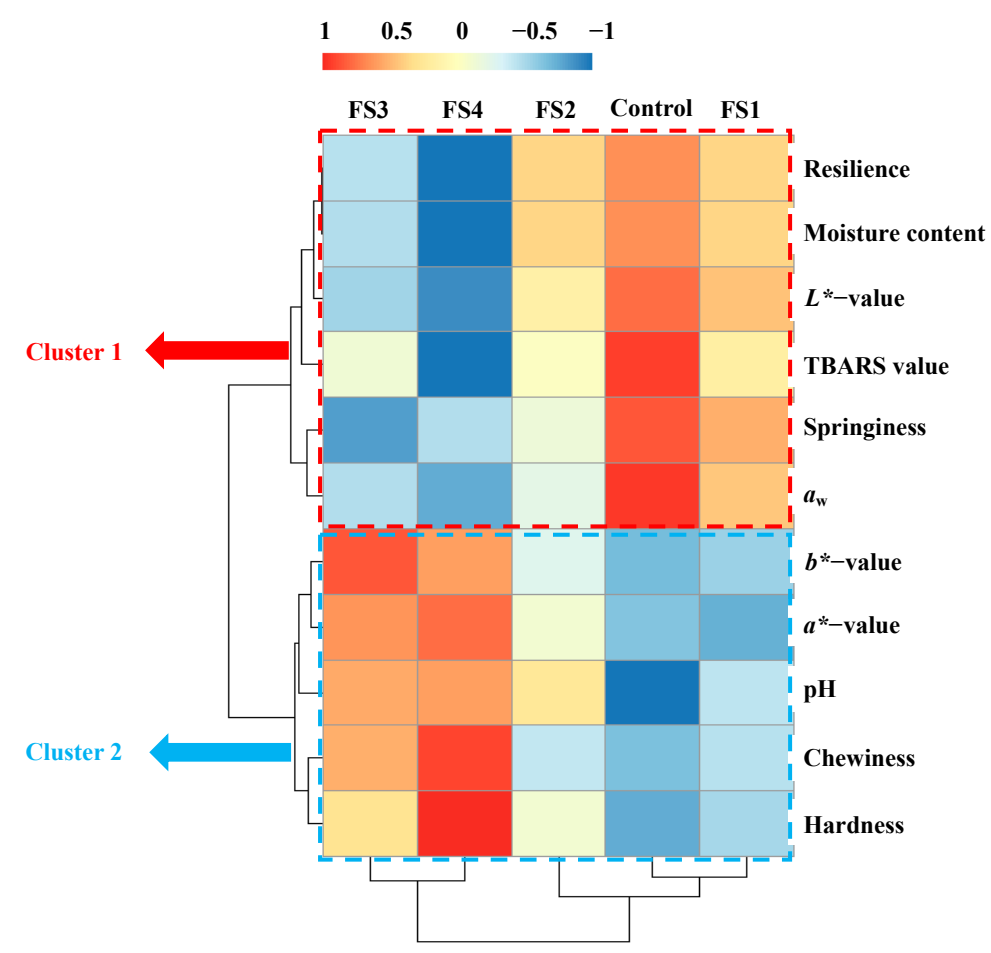

Figure 6. Hierarchical cluster analysis (HCA) of Harbin dry sausages with different replacement levels of CFS after fermentation. Control: 100\% backfat; FS1: $80 \%$ backfat and 20\% CFS; FS2: 60\% backfat and $40 \%$ CFS; FS3: $40 \%$ backfat and 60\% CFS; FS4: $20 \%$ backfat and $80 \%$ CFS.

\section{Conclusions}

In summary, from the results of the various analytical techniques, the partial replacement of back-fat with CFS was a feasible way to reduce the fat content of Harbin dry fermented sausages, depending on the replacement level. Compared with the control group, replacing 20 and $40 \%$ of the back-fat with CFS did not affect the physical and sensory characteristics of the sausage. However, when the replacement level reached $60 \%$ or more, the physical and sensory characteristics changed, as evidenced by the decreased moisture content and $a_{\mathrm{w}}$ and the increased $\mathrm{pH}$, hardness, chewiness and atypical appearance of the sausages. Additionally, E-nose analysis and HCA analysis affirmed the negative correlations between the control and the FS4 (80\% back-fat replacement) treatment in quality characteristics. It is noted that this study provides another option for food producers to replace animal with plant-based ingredients. Replacing up to $40 \%$ of animal fat with plant-based CFS can reduce the environmental footprint of Harbin dry sausages, 
make them healthier for consumers and more ethical without significantly affecting their sensory or physical characteristics. Further research will focus on the following two aspects: (1) how to effectively retard the moisture evaporation of the CFS, which could probably improve the fat replacement levels, as well as promote quality characteristics of Harbin dry sausages; (2) optimising the technological conditions to improve the production technology and quality of low-fat Harbin dry fermented sausages.

Author Contributions: Methodology, investigation and writing-original draft, J.C.; software, visualization and investigation, J.Z.; methodology, resources and investigation, X.L.; conceptualization, funding acquisition, supervision and writing-review and editing, Q.L.; data curation and formal analysis, B.K. All authors have read and agreed to the published version of the manuscript.

Funding: This study was supported by the Foundation of Central Support for the Reform and Development of Local Universities in Heilongjiang Province (Excellent Young Talents Project) (Grant No. 2020YQ15) and the Heilongjiang Major Science and Technology Projects (Grant No. 2020ZX07B02).

Institutional Review Board Statement: Not applicable.

Informed Consent Statement: Not applicable.

Data Availability Statement: The data presented in this study are available in the article.

Conflicts of Interest: The authors declare no conflict of interest.

\section{References}

1. Chen, Q.; Kong, B.; Han, Q.; Xia, X.; Xu, L. The role of bacterial fermentation in lipolysis and lipid oxidation in Harbin dry sausages and its flavour development. LWT Food Sci. Technol. 2017, 77, 389-396. [CrossRef]

2. Ruiz-Capillas, C.; Triki, M.; Herrero, A.; Rodriguez-Salas, L.; Jiménez-Colmenero, F. Konjac gel as pork backfat replacer in dry fermented sausages: Processing and quality characteristics. Meat Sci. 2012, 92, 144-150. [CrossRef] [PubMed]

3. Bray, G.A.; Paeratakul, S.; Popkin, B. Dietary fat and obesity: A review of animal, clinical and epidemiological studies. Physiol. Behav. 2004, 83, 549-555. [CrossRef] [PubMed]

4. Choi, Y.-S.; Choi, J.-H.; Han, D.-J.; Kim, H.-Y.; Lee, M.-A.; Kim, H.-W.; Lee, J.-W.; Chung, H.-J.; Kim, C.-J. Optimization of replacing pork back fat with grape seed oil and rice bran fiber for reduced-fat meat emulsion systems. Meat Sci. 2010, 84, 212-218. [CrossRef]

5. Chen, Y.; Jia, X.; Sun, F.; Jiang, S.; Liu, H.; Liu, Q.; Kong, B. Using a stable pre-emulsified canola oil system that includes porcine plasma protein hydrolysates and oxidized tannic acid to partially replace pork fat in frankfurters. Meat Sci. 2020, 160, 107968. [CrossRef] [PubMed]

6. World Health Organization (WHO). Available online: https://www.who.int/publications/i/item/924120916X (accessed on 28 January 2002).

7. Chinese Dietary Guidelines (CDG). Available online: http://dg.cnsoc.org/article/04/8a2389fd575f695101577a31ca7602d5.html (accessed on 30 September 2016).

8. Muguerza, E.; Fista, G.; Ansorena, D.; Astiasaran, I.; Bloukas, J. Effect of fat level and partial replacement of pork backfat with olive oil on processing and quality characteristics of fermented sausages. Meat Sci. 2002, 61, 397-404. [CrossRef]

9. Liaros, N.; Katsanidis, E.; Bloukas, J. Effect of the ripening time under vacuum and packaging film permeability on processing and quality characteristics of low-fat fermented sausages. Meat Sci. 2009, 83, 589-598. [CrossRef]

10. Olivares, A.; Navarro, J.L.; Salvador, A.; Flores, M. Sensory acceptability of slow fermented sausages based on fat content and ripening time. Meat Sci. 2010, 86, 251-257. [CrossRef]

11. Koutsopoulos, D.; Koutsimanis, G.; Bloukas, J. Effect of carrageenan level and packaging during ripening on processing and quality characteristics of low-fat fermented sausages produced with olive oil. Meat Sci. 2008, 79, 188-197. [CrossRef]

12. Zhu, Y.; Guo, L.; Tang, W.; Yang, Q. Beneficial effects of Jerusalem artichoke powder and olive oil as animal fat replacers and natural healthy compound sources in Harbin dry sausages. Poult. Sci. 2020, 99, 7147-7158. [CrossRef]

13. Al-Ghazzewi, F.H.; Khanna, S.; Tester, R.F.; Piggott, J. The potential use of hydrolysed konjac glucomannan as a prebiotic. J. Sci. Food Agric. 2007, 87, 1758-1766. [CrossRef]

14. Wang, X.; Xie, Y.; Li, X.; Liu, Y.; Yan, W. Effects of partial replacement of pork back fat by a camellia oil gel on certain quality characteristics of a cooked style Harbin sausage. Meat Sci. 2018, 146, 154-159. [CrossRef]

15. Alejandre, M.; Poyato, C.; Ansorena, D.; Astiasarán, I. Linseed oil gelled emulsion: A successful fat replacer in dry fermented sausages. Meat Sci. 2016, 121, 107-113. [CrossRef]

16. Jiménez-Colmenero, F.; Triki, M.; Herrero, A.M.; Rodríguez-Salas, L.; Ruiz-Capillas, C. Healthy oil combination stabilized in a konjac matrix as pork fat replacement in low-fat, PUFA-enriched, dry fermented sausages. LWT-Food Sci. Technol. 2013, 51, 158-163. [CrossRef] 
17. Campagnol, P.C.B.; dos Santos, B.A.; Wagner, R.; Terra, N.N.; Pollonio, M.A.R. Amorphous cellulose gel as a fat substitute in fermented sausages. Meat Sci. 2012, 90, 36-42. [CrossRef]

18. Zhang, S.; Zhao, S.C.; Jia, X.W.; Cao, C.A.; Kong, B.H.; Liu, Q. Effect of different gelling agents on the physical and chemical properties of cube fat analogue. Food Res. Develop. 2018, 39, 12-18. (In Chinese)

19. Chen, Q.; Kong, B.; Sun, Q.; Dong, F.; Liu, Q. Antioxidant potential of a unique LAB culture isolated from Harbin dry sausage: In vitro and in a sausage model. Meat Sci. 2015, 110, 180-188. [CrossRef]

20. Association of Official Analytical Chemists (AOAC). Available online: https://www.aoac.org/?s=Association+of + Official+ Analytical+Chemists (accessed on 16 November 1995).

21. Chen, J.; Hu, Y.; Wen, R.; Liu, Q.; Chen, Q.; Kong, B. Effect of $\mathrm{NaCl}$ substitutes on the physical, microbial and sensory characteristics of Harbin dry sausage. Meat Sci. 2019, 156, 205-213. [CrossRef]

22. Sun, Q.; Zhao, X.; Chen, H.; Zhang, C.; Kong, B. Impact of spice extracts on the formation of biogenic amines and the physicochemical, microbiological and sensory quality of dry sausage. Food Control. 2018, 92, 190-200. [CrossRef]

23. Wen, R.; Hu, Y.; Zhang, L.; Wang, Y.; Chen, Q.; Kong, B. Effect of NaCl substitutes on lipid and protein oxidation and flavor development of Harbin dry sausage. Meat Sci. 2019, 156, 33-43. [CrossRef] [PubMed]

24. Yin, X.; Wen, R.; Sun, F.; Wang, Y.; Kong, B.; Chen, Q. Collaborative analysis on differences in volatile compounds of Harbin red sausages smoked with different types of woodchips based on gas chromatography-mass spectrometry combined with electronic nose. LWT Food Sci. Technol. 2021, 143, 111144. [CrossRef]

25. Yin, X.; Lv, Y.; Wen, R.; Wang, Y.; Chen, Q.; Kong, B. Characterization of selected Harbin red sausages on the basis of their flavour profiles using HS-SPME-GC/MS combined with electronic nose and electronic tongue. Meat Sci. 2021, 172, 108345. [CrossRef]

26. Kong, B.; Xiong, Y.L.; Fang, C.; Thompson, K.R.; Metts, L.S.; Muzinic, L.A.; Webster, C.D. Influence of Gender and Spawning on Meat Quality of Australian Red Claw Crayfish (Cherax quadricarinatus) Stored at $2{ }^{\circ}$ C. J. Food Sci. 2006, 71, E320-E325. [CrossRef]

27. International Standard Organisation (ISO). Available online: https://www.iso.org/standard/50125.html (accessed on 1 December 2014).

28. International Standard Organisation (ISO). Available online: https://www.iso.org/standard/36385.html (accessed on 1 December 2007).

29. Jiang, S.; Zhao, S.; Jia, X.; Wang, H.; Zhang, H.; Liu, Q.; Kong, B. Thermal gelling properties and structural properties of myofibrillar protein including thermo-reversible and thermo-irreversible curdlan gels. Food Chem. 2020, 311, 126018. [CrossRef]

30. Bolin, H.R. Relation of Moisture to Water Acitivity in Prunes and Raisins. J. Food Sci. 1980, 45, 1190-1192. [CrossRef]

31. García, M.L.; Dominguez, R.; Galvez, M.; Casas, C.; Selgas, M. Utilization of cereal and fruit fibres in low fat dry fermented sausages. Meat Sci. 2002, 60, 227-236. [CrossRef]

32. Mendoza, E.; García, M.L.; Casas, C.; Selgas, M. Inulin as fat substitute in low fat, dry fermented sausages. Meat Sci. 2001, 57, 387-393. [CrossRef]

33. Wang, Y.; Li, F.; Zhuang, H.; Chen, X.; Li, L.; Qiao, W.; Zhang, J. Effects of plant polyphenols and $\alpha$-tocopherol on lipid oxidation, residual nitrites, biogenic amines, and N-nitrosamines formation during ripening and storage of dry-cured bacon. LWT-Food Sci. Technol. 2015, 60, 199-206. [CrossRef]

34. Ulu, H. Evaluation of three 2-thiobarbituric acid methods for the measurement of lipid oxidation in various meats and meat products. Meat Sci. 2004, 67, 683-687. [CrossRef]

35. Triki, M.; Herrero, A.M.; Rodríguez-Salas, L.; Colmenero, F.J.; Ruiz-Capillas, C. Chilled storage characteristics of low-fat, n-3 PUFA-enriched dry fermented sausage reformulated with a healthy oil combination stabilized in a konjac matrix. Food Control. 2013, 31, 158-165. [CrossRef]

36. Valencia, I.; Ansorena, D.; Astiasarán, I. Nutritional and sensory properties of dry fermented sausages enriched with $\mathrm{n}-3$ PUFAs. Meat Sci. 2006, 72, 727-733. [CrossRef]

37. Josquin, N.M.; Linssen, J.P.; Houben, J.H. Quality characteristics of Dutch-style fermented sausages manufactured with partial replacement of pork back-fat with pure, pre-emulsified or encapsulated fish oil. Meat Sci. 2012, 90, 81-86. [CrossRef]

38. Škaljac, S.; Jokanović, M.; Tomović, V.; Ivić, M.; Tasić, T.; Ikonić, P.; Šojić, B.; Džinić, N.; Petrović, L. Influence of smoking in traditional and industrial conditions on colour and content of polycyclic aromatic hydrocarbons in dry fermented sausage "Petrovská klobása". LWT Food Sci. Technol. 2018, 87, 158-162. [CrossRef]

39. Liu, P.; Wang, S.; Zhang, H.; Wang, H.; Kong, B. Influence of glycated nitrosohaemoglobin prepared from porcine blood cell on physicochemical properties, microbial growth and flavour formation of Harbin dry sausages. Meat Sci. 2019, 148, 96-104. [CrossRef]

40. Utrilla, M.; Ruiz, A.G.; Soriano, A. Effect of partial reduction of pork meat on the physicochemical and sensory quality of dry ripened sausages: Development of a healthy venison salchichon. Meat Sci. 2014, 98, 785-791. [CrossRef]

41. Mora-Gallego, H.; Guàrdia, M.D.; Serra, X.; Gou, P.; Arnau, J. Sensory characterisation and consumer acceptability of potassium chloride and sunflower oil addition in small-caliber non-acid fermented sausages with a reduced content of sodium chloride and fat. Meat Sci. 2016, 112, 9-15. [CrossRef] [PubMed]

42. Mora-Gallego, H.; Serra, X.; Guàrdia, M.D.; Arnau, J. Effect of reducing and replacing pork fat on the physicochemical, instrumental and sensory characteristics throughout storage time of small caliber non-acid fermented sausages with reduced sodium content. Meat Sci. 2014, 97, 62-68. [CrossRef] 
43. Chen, Q.; Hu, Y.; Wen, R.; Wang, Y.; Qin, L.; Kong, B. Characterisation of the flavour profile of dry fermented sausages with different $\mathrm{NaCl}$ substitutes using HS-SPME-GC-MS combined with electronic nose and electronic tongue. Meat Sci. 2021, 172, 108338. [CrossRef] [PubMed]

44. Zhang, J.; Cao, J.; Pei, Z.; Wei, P.; Xiang, D.; Cao, X.; Shen, X.; Li, C. Volatile flavour components and the mechanisms underlying their production in golden pompano (Trachinotus blochii) fillets subjected to different drying methods: A comparative study using an electronic nose, an electronic tongue and SDE-GC-MS. Food Res. Int. 2019, 123, 217-225. [CrossRef] [PubMed]

45. Chen, Q.; Song, J.; Bi, J.; Meng, X.; Wu, X. Characterization of volatile profile from ten different varieties of Chinese jujubes by HS-SPME/GC-MS coupled with E-nose. Food Res. Int. 2018, 105, 605-615. [CrossRef] [PubMed]

46. Wang, S.; Lin, R.; Cheng, S.; Tan, M. Water dynamics changes and protein denaturation in surf clam evaluated by two-dimensional LF-NMR T1-T2 relaxation technique during heating process. Food Chem. 2020, 320, 126622. [CrossRef] [PubMed] 